FETAL AND NEONATAL EDITION

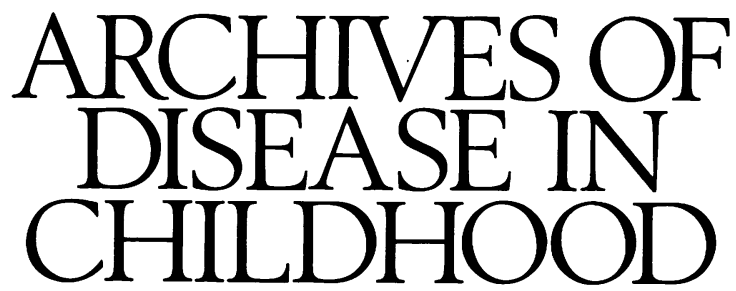

The Fournal of the British Paediatric Association

\title{
Annotations
}

\section{Varicella zoster virus infection in pregnancy}

Primary maternal varicella zoster virus infection (chickenpox) during pregnancy can have devastating effects on the mother, the fetus, and the newborn. Maternal shingles, that is reactivation of latent maternal varicella zoster virus infection, can also affect the fetus, albeit less commonly.

For varicella zoster virus infections, $T$ cells are of prime importance in recovery from acute infection, while antibodies can protect against infection, or at least against severity of infection, but are not primarily involved in recovery. People with impaired cellular immunity, such as those on cytotoxic treatment, tend to get severe and sometimes fatal varicella, whereas children with hypogammaglobulinaemia recover normally from chickenpox.

\section{Incidence of varicella in pregnancy}

Chickenpox is not notifiable, except in Scotland, and even in prospective studies mild cases are probably not reported, while asymptomatic cases may occur. In a large prospective study documented maternal chickenpox occurred in five per 10000 pregnancies in the United States. ${ }^{1}$ However, adults from tropical or subtropical areas are more likely to be susceptible to varicella. ${ }^{2}$ Kjersem and Jepsen evaluated the incidence of varicella in Tamil refugees in Denmark. ${ }^{3}$ Nine of 44 fertile women were pregnant and two of these acquired varicella infection during the first trimester, none in relation to delivery. Among 118 cases of chickenpox in pregnant North American women, 24 women developed chickenpox pneumonia and 11 of them died. ${ }^{4}$ Thus primary maternal chickenpox appears to be abnormally severe, presumably due to depressed cellular immunity in pregnancy.

\section{Varicella in the first trimester}

The composite risk of congenital varicella syndrome after first trimester chickenpox infection in four studies was $2.3 \%(3 / 131)$ with $95 \%$ confidence intervals of 0.5 to $6.5 \% .^{5}$ The risks of congenital infection after first trimester maternal zoster, ${ }^{6}$ or primary chickenpox in the second 7 or third trimester ${ }^{8}$ are much lower, although affected babies have been described after each of these scenarios. La Foret and Lynch were the first to describe an association between maternal varicella infection in early pregnancy and congenital anomalies in the offspring. ${ }^{9}$ Alkalay et al have proposed specific criteria for documenting the association between maternal varicella infection in early pregnancy and neonatal abnormalities. ${ }^{10}$
Evidence of maternal varicella infection during pregnancy and the presence of cicatricial skin lesions that correspond to a dermatome distribution, often with shortening of the affected limb, are essential. Serological confirmation (varicella zoster virus specific IgM or persistently raised IgG in the baby) provides additional evidence. Alkalay et al described the following characteristics in 22 infants with a congenital varicella syndrome: female (85\%), small for dates $(39 \%)$, premature $(38 \%)$, neurological anomalies, particularly microcephaly and cerebellar hypoplasia $(77 \%)$, eye anomalies, mainly microphthalmia and cataracts $(68 \%)$, skeletal anomalies $(68 \%)$, gastrointestinal anomalies (23\%), and genitourinary anomalies $(23 \%) .{ }^{10}$ The risk of spontaneous abortion after first trimester chickenpox is not significantly increased. ${ }^{11}$

\section{Management of pregnant women}

Protection of the fetus cannot be assumed if a susceptible, exposed woman receives varicella zoster immunoglobulin (ZIG) and does not develop signs of chickenpox. ${ }^{5}$ However, ZIG for pregnant susceptible women exposed to chickenpox may be indicated because of the increased severity of chickenpox in pregnancy. Should chickenpox pneumonitis supervene, aggressive treatment with acyclovir and possibly ventilation should be commenced..$^{12}$ There is no information on whether treating maternal first trimester chickenpox with acyclovir can lessen the risk of congenital varicella syndrome.

\section{Perinatal chickenpox}

Around $95 \%$ of women of childbearing age have already had chickenpox. If a pregnant woman develops chickenpox around the time of delivery, her baby may develop life threatening illness. Only about a quarter of the babies of mothers who develop chickenpox during the last 21 days of pregnancy become infected. ${ }^{4}$ The severity of the baby's illness is determined by the timing of the mother's illness in relation to delivery. Erlich et al noted that if the baby was born with a rash, or the rash appeared within four days of birth, the baby survived, whereas $30 \%$ of babies whose rash developed five to 10 days after birth died from disseminated chickenpox, usually with severe pneumonitis. ${ }^{15}$ The incubation period for congenital varicella (time between mother's and baby's rash) is about nine to 15 days, although it may be much shorter if the mother is very viraemic. The corollary of the timing of the 
Table 1 Timing of chickenpox in mother and baby in relation to severity ${ }^{15}$

\begin{tabular}{lllll}
\hline $\begin{array}{l}\text { Onset of mother's } \\
\text { rash in relation } \\
\text { to delivery }\end{array}$ & $\begin{array}{l}\text { Onset of baby's } \\
\text { rash in relation } \\
\text { to delivery (days) }\end{array}$ & No died & No survived & $\begin{array}{l}\text { Neonatal } \\
\text { mortality } \\
\text { (\%) }\end{array}$ \\
\hline $\begin{array}{l}\text { 5-21 days before } \\
4 \text { days before to }\end{array}$ & $0-4$ & 0 & 27 & 0 \\
\begin{tabular}{l}
2 days after \\
\hline
\end{tabular} & $5-10$ & 7 & 16 & 30 \\
\hline
\end{tabular}

Table 2 Timing of mother's chickenpox in relation to presence of antibodies in baby 16

\begin{tabular}{ll}
\hline $\begin{array}{l}\text { Time before delivery of } \\
\text { onset of mother's rash } \\
\text { (days) }\end{array}$ & $\begin{array}{l}\text { Proportion of babies } \\
\text { with detectable antibody } \\
\text { (IgG titre } \leq 32)\end{array}$ \\
\hline $0-2$ & $0 / 26$ \\
$3-5$ & $11 / 23$ \\
$\leq 6$ & $18 / 18$ \\
\hline
\end{tabular}

baby's rash was that when the mother's rash appeared five or more days before delivery the baby survived, whereas if the mother's rash appeared four days before to two days after delivery then the mortality was about $30 \%$ (table 1 ). This later observation is the most important for clinical decision making.

The reason for the importance of the timing of maternal varicella appears to be that severely affected babies acquire a large transplacental inoculum of virus, secondary to maternal viraemia, before maternal IgG antibody specific to the virus has crossed the placenta. It is thought that this results in widespread seeding of the virus, which can replicate in multiple sites. Babies are born well, but become severely ill at 5 to 10 days. Miller et al have shown that babies whose mother's rash develops six or more days before delivery all have detectable IgG antibody, whereas if the mother's rash develops later, antibody is often undetectable (table 2). ${ }^{16}$

\section{Management of perinatal chickenpox}

ZIG, immunoglobulin prepared from donors with a high titre to varicella zoster virus, is generally effective in ameliorating the severity of infection, although it does not actually prevent infection. Hanngren et al gave ZIG to 95 babies with perinatal exposure and $48(50 \%)$ developed chickenpox. ${ }^{17}$ Of the 41 babies in the maximum risk group (mother's chickenpox four days before delivery to two days after delivery), 21 became infected of which two cases were severe. ZIG has not been standardised and the effective dose is not known. Severe neonatal varicella, sometimes fatal, may rarely occur despite giving ZIG at delivery. ${ }^{18} 19$

The antiviral treatment of babies with severe varicella infection is intravenous acyclovir $(60 \mathrm{mg} / \mathrm{kg} /$ day given every eight hours) but deaths from severe pneumonitis have occurred despite early treatment. ${ }^{18}$

There are fewer data for babies whose mother's rash develops after delivery. The babies have no transplacental antibody but may receive a lesser viral inoculum. The longer after delivery the mother's rash occurs, the less likely the baby is to have received virus transplacentally.

Given the importance of the timing of the maternal rash, it may be worth attempting to delay labour for a few days if a labouring mother had recent chickenpox. This is obviously easier in spontaneous or elective preterm labour, but consideration could be given to trying to prevent term labour from progressing.

\section{Recommendation \\ Babies whose mothers developed chickenpox rash up to and including five days before delivery or up to two days after delivery should be given intramus- cular ZIG as soon as possible.}

\section{Postnatal chickenpox}

A neonate whose mother has not had chickenpox and who is exposed to chickenpox postnatally, as opposed to perinatally, usually from a sibling or occasionally a parent, may be at slightly increased risk of severe infection, although the risk is difficult to quantify because of selective reporting. Rubin et al reviewed the literature and found four cases of severe postnatally acquired neonatal chickenpox, including one child whose mother had a history of chickenpox. ${ }^{20}$ It is not clear that these cases indicate that neonates with postnatal chickenpox are at increased risk, as apparently normal children and adults may rarely develop severe chickenpox.

A common situation is that a sibling at home has chickenpox at the time a mother and newborn baby are due to be discharged from hospital. If the mother has had chickenpox the risk to the baby is minimal and mother and baby can safely be sent home. If the mother gives no history of chickenpox she may have had subclinical infection and her serum should be tested for varicella zoster virus antibodies. If the mother has no antibodies it seems reasonable to send the mother and baby home after giving the baby ZIG.

DAVID McINTOSH DAVID ISAACS

Department of Immunology and Infectious Diseases,

Royal Alexandra Hospital for Children,

Camperdown, NSW 2050,

Australia

1 Sever JA, White LR. Intrauterine viral infections. Annu Rev Med 1969; 19:471-86

2 Gershon AA, Raker R, Steinberg S, Topf-Olstein B, Drusin LM. Antibody to varicella-zoster virus in parturient women and their offspring during the first year of life. Pediatrics 1976;58:692-6.

the first year of life. Pediatrics 1976;58:692-6.
3 Kiersem H, Jepsen S. Varicella among immigrants from the tropics, a health problem. Scand $\mathcal{F}$ Soc Med 1990;18:171-4.

4 Gershon AA. Chickenpox, measles and mumps. In: Remington JS, Klein $\mathrm{JO}$, eds. Infectious diseases of the fetus and newborn infant. 3rd Ed Philadelphia: W B Saunders, 1990:395-445.

5 Preblud SR, Cochi SL, Orenstein WA. Varicella-zoster infection in preg nancy. $N$ Engl f Med 1986;315:1416-7.

6 Webster MH, Smith CS. Congenital abnormalities and maternal herpe zoster. BMF 1977;ii: 1193.

7 Brice JEH. Congenital varicella resulting from infection during second trimester of pregnancy. Arch Dis Child 1976;51:474-6.

8 Bai PVA, John TJ. Congenital skin ulcers following varicella in late preg-

nancy. $\mathcal{F}$ Pediatr 1979;94:65-7.
9 La Foret, Lynch LL. Multiple congenital defects following maternal varicella. N Engl f Med 1947;236:534-7.

10 Alkalay AL, Pomerance JJ, Rimoin DL. Fetal varicella syndrome. $\mathcal{F}$ Pediatr 1987;111:320-3.

11 Siegel M, Fuerst HT, Peress NS. Comparative fetal mortality in maternal virus diseases. N Engl f Med 1966;274:768-71.

12 Cox SM, Cunningham FG, Luby J. Management of pneumonia complicating pregnancy. Am f Perinatol 1990;7:300-1.

13 Broussard RC, Payne DK, George RB. Treatment with acyclovir of varicella pneumonia in pregnancy. Chest 1991;99:1045-7.

14 Meyer JD. Congenital varicella in term infants; risk reconsidered. $\mathcal{F}$ Infect Dis 1974;129:125-7.

15 Erlich RM, Turner JAP, Clarke M. Neonatal varicella. f Pediatr 1958 ; 53:139-47.

16 Miller E, Cradock-Watson JE, Ridehalgh MKS. Outcome of newborn babies given anti-varicella-zoster immunoglobulin after perinatal infection with varicella-zoster virus. Lancet 1989;ii:371-3.

17 Hanngren K, Grandien M, Granstrom G. Effect of zoster immunoglobulin for varicella prophylaxis in the newborn. Scand $f$ Infect Dis for varicella pro

18 Holland P, Isaacs D, Moxon ER. Fatal neonatal varicella infection. Lancet 1986;ii: 1156.

19 Bakshi SS, Miller TC, Kaplan M, Hammerschlag MR, Prince A, Gershon AA. Failure of varicella-zoster immunoglobulin in modification of severe congenital varicella. Pediatr Infect Dis $\mathcal{F}$ 1986;5:699-702.

20 Rubin I varicella in a neonate: implications for immunoprophylaxis of neonates exposed to varicella. Pediatr Infect Dis $\mathcal{f} 1986 ; 5: 100-2$. 